\title{
Effects of Lidocaine and Ropivacaine on Gastric Cancer Cells Through Down-regulation of ERK1/2 Phosphorylation In Vitro
}

\author{
WENJING YANG ${ }^{1,2}$, JUN CAI $^{2}$, HUIMING ZHANG $^{3}$, GUYAN WANG $^{1}$ and WENGUO JIANG ${ }^{2}$ \\ ${ }^{1}$ Department of Anesthesiology, Beijing Tong Ren Hospital, Capital Medical University, Beijing, P.R. China; \\ ${ }^{2}$ Cardiff China Medical Research Collaborative, Cardiff University-Peking University Joint Cancer Institute, Henry \\ Wellcome Building, School of Medicine, Cardiff University, Cardiff, U.K.; \\ ${ }^{3}$ Department of General Surgery, Beijing Friendship Hospital Affiliated to \\ Capital Medical University, Beijing, P.R. China
}

\begin{abstract}
Background: Lidocaine and ropivacaine have been widely used in gastric cancer surgery. In recent years, lidocaine and ropivacaine have attracted increasing attention in cancer research, whilst effects of lidocaine and ropivacaine on gastric cancer cells have not been investigated before. This study explored the effect of lidocaine and ropivacaine on AGS and HGC-27 gastric cancer cells. Materials and Methods: AGS and HGC-27 cells were incubated with lidocaine or ropivacaine at concentrations of 10,100 and $1 \mathrm{mM}$. At 24, 48 and $72 \mathrm{~h}$ after treatment, proliferation and invasion were evaluated by crystal violet assay and transwell invasion assay. Electric cell-substrate impedance sensing was applied to measure the migration of cancer cells. Phosphorylation status of extracellular-regulated protein kinases (ERK1/2) was evaluated by western blot analysis. Results: Lidocaine $(1 \mathrm{mM})$ and ropivacaine $(1 \mathrm{mM})$ significantly inhibited the proliferation of AGS and HG-27 cells, but had no significant effects on invasion. Lidocaine $(1 \mathrm{mM})$ and ropivacaine ( $1 \mathrm{mM}$ ) also inhibited the migration of $\mathrm{AGS}$ and $\mathrm{HGC}$ 27cells. After treatment with lidocaine $(1 \mathrm{mM})$ or ropivacaine $(1 \mathrm{mM})$ for $24 \mathrm{~h}$, the phosphorylation of ERK1/2 in AGS and HGC-27 cells was reduced. Conclusion: Lidocaine at a clinically relevant concentration $(10 \mu \mathrm{M})$, and ropivacaine at $1 \mathrm{mM}$ inhibited the proliferation of gastric cancer cell lines by down-regulation of p-ERK1/2. The migration of HGC-27 cells, rather than AGS cells was more obviously inhibited by lidocaine $(1 \mathrm{mM})$ and
\end{abstract}

Correspondence to: Wenguo Jiang, MD, Cardiff University, Cardiff CF14 4XN, U.K. Tel: +44 2920687065, Fax: +44 2920687065, e-mail: jiangw@cardiff.ac.uk

Key Words: Gastric carcinoma, local anaesthetic, lidocaine, ropivacaine, proliferation. ropivacaine $(1 \mathrm{mM})$. This research is easy to implement, and lays a foundation for the future research of local anaesthetics in cancer.

Gastric cancer was the third leading cause of mortality throughout the world in $2013(1,2)$. Conventional therapeutic methods for gastric cancer are target-specific drug treatment (3), surgical excision (4), radiotherapy or chemotherapy (5). After surgery, the recurrence and metastasis of gastric cancer are pressing issues, and are complicated processes involved a series of events $(6,7)$, such as tumor heterogeneity, and epigenetic changes $(8,9)$. It has been confirmed that circulating tumour cells with the ability to diffuse and metastasize are a prime prognostic marker for cancer recurrence $(10,11)$. Even if patients undergo a complete resection of their tumour, circulating tumour cells shed from the tumour into the circulatory or lymphatic system, enabling the recurrence and metastasis of cancer (12). Therefore, after surgery cancer patients still need to take certain anticancer drugs and radiation treatment to prevent recurrence and metastasis. Anticancer drugs are usually expensive and have many side-effects (13). There is, therefore, a pressing need for new economic and highly effective anticancer drugs.

Local anaesthetics (LAs), which are cheap and affordable, are widely used peri-operatively to relieve pain by various modes, such as nerve block, epidural or subarachnoid injection, local infiltration and intravenous administration. A study has revealed that LAs have indirect effects on cancer progression. For example, application of LAs can reduce opioid consumption or stress response during the perioperative period (14). In addition, in vitro and in vivo studies showed that LAs might also have direct effects on certain tumour cells (e.g. breast, lung, liver and thyroid) (15-18). It has been reported that lidocaine inhibited the growth of HepG2 cells in a dose-dependent and time-dependent manner, arrested cells 
in the $\mathrm{G}_{0} / \mathrm{G}_{1}$ phase of the cell cycle and induced apoptosis (19). Lidocaine at $1 \mathrm{mM}$ was also shown to induce cell-cycle arrest in colon carcinoma cell lines in vitro (20). LAs have shown cytotoxic effects on neoplastic cells and T-lymphoma cells in vitro (21). Recent studies have also focused on the potential effects of LAs on the recurrence and metastasis of cancer. Growing evidence has shown that LAs can reduce the recurrence of cancer by indirect ways. For example, LAs have been shown to cause immunosuppression, stimulate malignant cells in vitro, induce an inflammatory response, and neuroendocrine and metabolic stress (22).

Lidocaine and ropivacaine are both amide-linked LAs which have been shown to induce apoptosis in human nonsmall cell lung cancer; they provoked DNA damage, upregulated reactive oxygen species (ROS) production and activated mitogen-activated protein kinase (MAPK) pathways (23). Retrospective clinical studies have shown better overall survival of patients after the application of LAs (22). As lidocaine and ropivacaine were widely used for anaesthesia and postoperative analgesia in gastric surgical operations, herein our study aimed to investigate whether lidocaine and ropivacaine have effects on gastric cancer cells.

\section{Materials and Methods}

Reagents. Commercially available lidocaine (Sigma-Aldrich, Saint Louis, MO, USA) and ropivacaine hydrochloride (Corden Pharma S.P.A., Caponago, Italy) were used in this study. Stock solutions of the agents were prepared by dissolving the drugs in sterile phosphatebuffered saline (PBS). The final concentration was achieved by diluting the stock solutions with standard growth medium.

Cell lines. Human gastric cancer cell lines AGS and HGC-27 were purchased from the European Collection of Cell Culture (Salisbury, UK). The cells were cultured in Dulbecco's modified Eagle's medium (DMEM) supplemented with $10 \%$ foetal calf serum (FCS; PAA Laboratories Ltd., Somerset, UK), amphotericin B, penicillin and streptomycin, and incubated at $37^{\circ} \mathrm{C}$ in a humidified atmosphere containing $5 \% \mathrm{CO}_{2}$ and $95 \%$ humidity.

Cell proliferation assay. Cell cultures cultivated at subconfluence were washed twice with PBS and detached with $0.05 \%$ trypsinEDTA. Cells were then re-suspended in culture medium with $10 \%$ foetal bovine serum (FBS), counted, and seeded into 96-well plates at a density of 3,000 cells $/ 200 \mu \mathrm{l}$ per well with different concentrations of lidocaine and ropivacaine, ranging from 0 to $1 \mathrm{mM}$. After incubation for 24,48 and $72 \mathrm{~h}$, the supernatant was removed and the plates were fixed in $4 \%$ formaldehyde $(\mathrm{v} / \mathrm{v})$ and stained with $0.5 \%(\mathrm{w} / \mathrm{v})$ crystal violet. Subsequently $10 \%$ acetic acid ( $\mathrm{v} / \mathrm{v})$ was added to the wells to dissolve the formazan crystals and the plates were incubated on a shaker for 10-15 min. The absorbance was measured at $540 \mathrm{~nm}$ using a Bio-Tek ELx800 multiplate reader (Bio-Tek Instruments Inc., Winnoski, VT, USA) and expressed as optical density units (OD).

Invasion assay. Transwell inserts with an $8 \mu \mathrm{m}$ pore size were coated with $50 \mu \mathrm{g}$ Matrigel/100 $\mu \mathrm{l}$ (BD Matrigel ${ }^{\mathrm{TM}}$ Basement Membrane
Matrix (Becton, Dickinson and Company, Bedford, OH, USA) and incubated for $30 \mathrm{~min}$ at $37^{\circ} \mathrm{C}$ prior to use. The AGS and HGC-27 cells re-suspended with normal medium including $1 \%$ FCS and different concentrations of lidocaine or ropivacaine $(0 \mu \mathrm{M}, 10 \mu \mathrm{M}, 100 \mu \mathrm{M}$ and $1 \mathrm{mM})$ were seeded in the upper chambers $\left(1 \times 10^{5}\right.$ in $\left.200 \mu \mathrm{l}\right)$. The bottom chamber was filled with normal medium $(600 \mu \mathrm{l})$ enriched with $10 \%$ FBS. After incubation for $24 \mathrm{~h}$, the cells that did not penetrate the polycarbonate filter membrane were removed with a clean cotton swab. The cells migrated through the matrix and pores were fixed with $4 \%$ formalin, stained in crystal violet and. The absorbance was measured at $540 \mathrm{~nm}$ using a Bio-Tek ELx800 multiplate reader (Bio-Tek Instruments Inc., Winnoski, VT, USA) and expressed as optical density units (OD).

Electric cell-substrate impedance sensing (ECIS) analysis of cell migration. An ECIS 9600 system (Applied Biophysics Inc., Troy, NJ, USA) was used to detect and track cell adhesion and migration. 96W1E ECIS arrays were used in the present study. ECIS measures the interaction between cells and the substrate to which they were attached via gold-film electrodes placed on the surface of culture dishes. An identical number of AGS or HGC-27 cells were added into each well, with different concentrations $(0 \mu \mathrm{M}, 10 \mu \mathrm{M}, 100 \mu \mathrm{M}$ and $1 \mathrm{mM})$ of lidocaine or ropivacaine. For the cell migration assay, after 10-h incubation, confluent cells were wounded. Wounding conditions were optimised for each cell line (for AGS, $20 \mathrm{~s}, 3,000 \mu \mathrm{A}, 60,000 \mathrm{~Hz}$; for HGC-27, $20 \mathrm{~s}, 1,400 \mu \mathrm{A}, 60,000 \mathrm{~Hz})$. After wounding for up to $4 \mathrm{~h}$, the migration of the cells was immediately traced again with multiple frequencies. Cell migration is represented here as resistance variation.

Western blot analysis. The AGS and HGC-27 cells were seeded into 6 -well plates $\left(1 \times 10^{6}\right.$ cells/well). The protein expression of phosphorylation status of extracellular-regulated protein kinases (p-ERK1/2) and $\beta$-actin were assessed by western blot, after incubation with and without $1 \mathrm{mM}$ lidocaine or ropivacaine for $24 \mathrm{~h}$. The cells were then lysed with lysis buffer and centrifuged $(14,000 \times g$ for $15 \mathrm{~min})$ for the extraction of total protein. The concentration of total protein was analysed through bicinchoninic acid assay. Total proteins in each group were separated by $10 \%$ sodium dodecyl sulfate-polyacrylamide gel electrophoresis. The proteins were then electrically transferred onto a nitrocellulose membrane and bound with anti-p-ERK1/2 and $\beta$-actin antibodies (1:2,000; Santa Cruz Biotechnology, Santa Cruz CA, USA) respectively. The membranes were incubated with secondary antimouse IgG (Sigma-Aldrich). Images of the protein bands were obtained through a chemiluminescence detection kit (Merck Millipore, Darmstadt, Germany) and a UvITech imager (UvITech, Cambridge, UK).

Statistically analysis. IBM SPSS 23 (IBM, Armonk, NY, USA) was used to identify statistical differences between the test groups through one-way analysis of variance (ANOVA) tests. All the experiments in this study were repeated at least three times.

\section{Results}

Cell proliferation assay. As shown in Figure 1A and B, lidocaine suppressed proliferation of AGS and HGC-27 at concentrations ranging from $10 \mu \mathrm{M}$ to $1 \mathrm{mM}$ compared with control. As shown in Figure 1C, ropivacaine at $1 \mathrm{mM}$ 

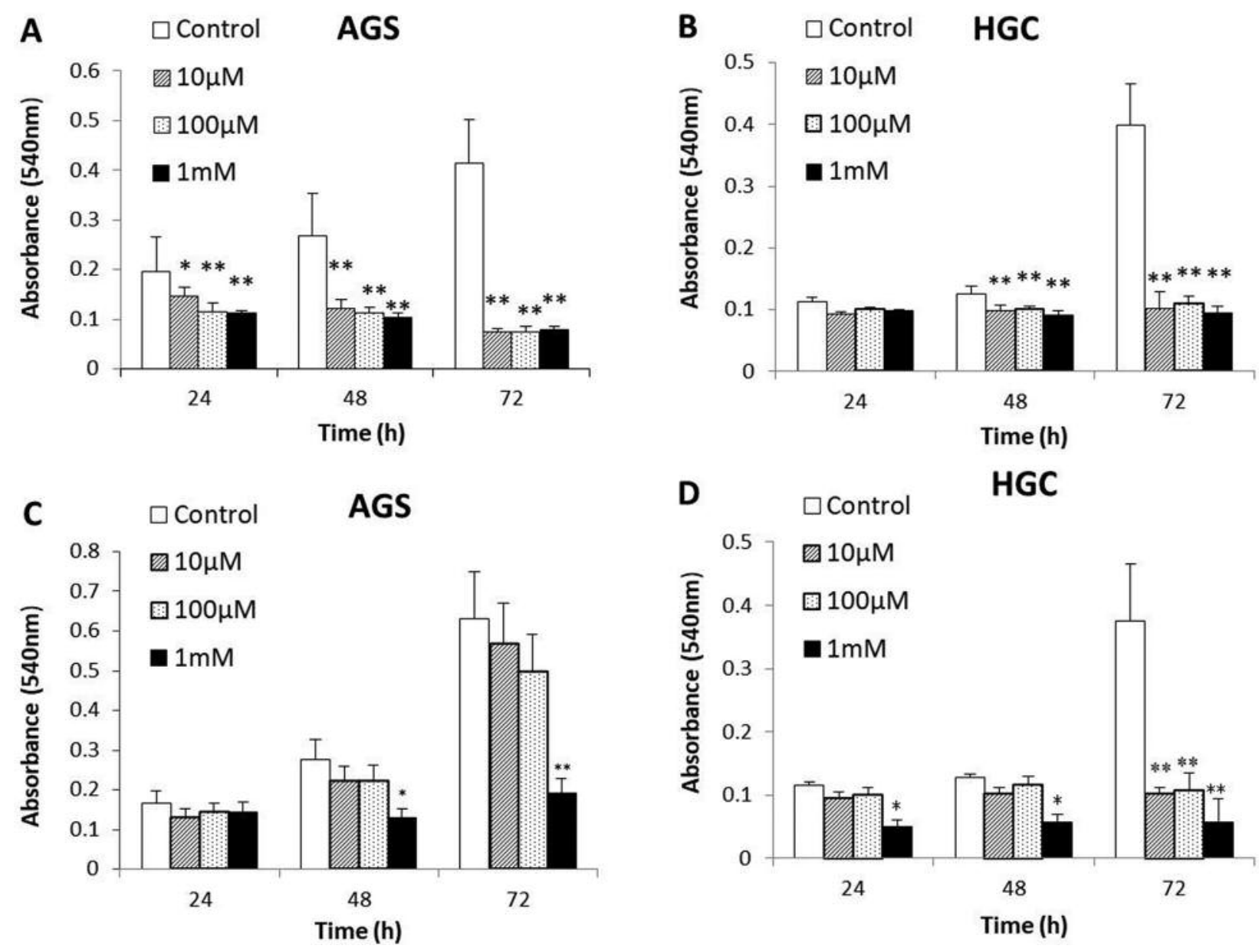

Figure 1. The antiproliferative effects of lidocaine on AGS (A) and HGC-27 (B) cells and of ropivacaine on AGS (C) and HGC-27 (D) cells. Significantly different at $* p<0.05$ and $* * p<0.01$ compared with control. The data are means $\pm S D$.

inhibited the proliferation of AGS cells significantly and the effects exhibit concentration dependency. For HGC-27 cells (Figure 1D), ropivacaine at high concentration clearly inhibited proliferation compared with the control.

Cell migration assay. Compared to the control, $1 \mathrm{mM}$ lidocaine and $1 \mathrm{mM}$ ropivacaine significantly reduced HGC27 cell migration $(p=0.024)$ (Figure $2 \mathrm{C}$ and D). No significant differences were found in those groups using lower concentrations $(p=0.139)$. Compared with the control group, $1 \mathrm{mM}$ lidocaine inhibited AGS cell migration significantly. Ropivacaine had a lesser effect on AGS cell migration compared with lidocaine and did not lead to significant differences at any concentration $(p=0.718)$ (Figure 2A and B).

Cell invasion. Compared to the control group, invasion of AGS and HGC-27 cells treated with different concentrations of lidocaine and ropivacaine did differ not significantly (Figure 3).

Western blot analysis. The quantitative analysis showed that the phosphorylation of ERK1/2 in AGS and HGC-27 cells decreased significantly $(p=0.001)$ after treatment with $1 \mathrm{mM}$ lidocaine and ropivacaine for 24 hours (Figure 4B).

\section{Discussion}

In this study, we found that lidocaine and ropivacaine inhibited the proliferation of AGS and HGC-27 cells within $72 \mathrm{~h}$, especially lidocaine at doses of $10 \mu \mathrm{M}$ or above, which is safe as the blood level for clinical use.

It has been reported that lidocaine has antiproliferative effects on human hepatocarcinoma cells, in time-and dosedependent manners. (16) Furthermore, a study revealed that lidocaine suppressed the growth of human hepatocellular carcinoma in a xenograft model in vivo (17). As lidocaine 

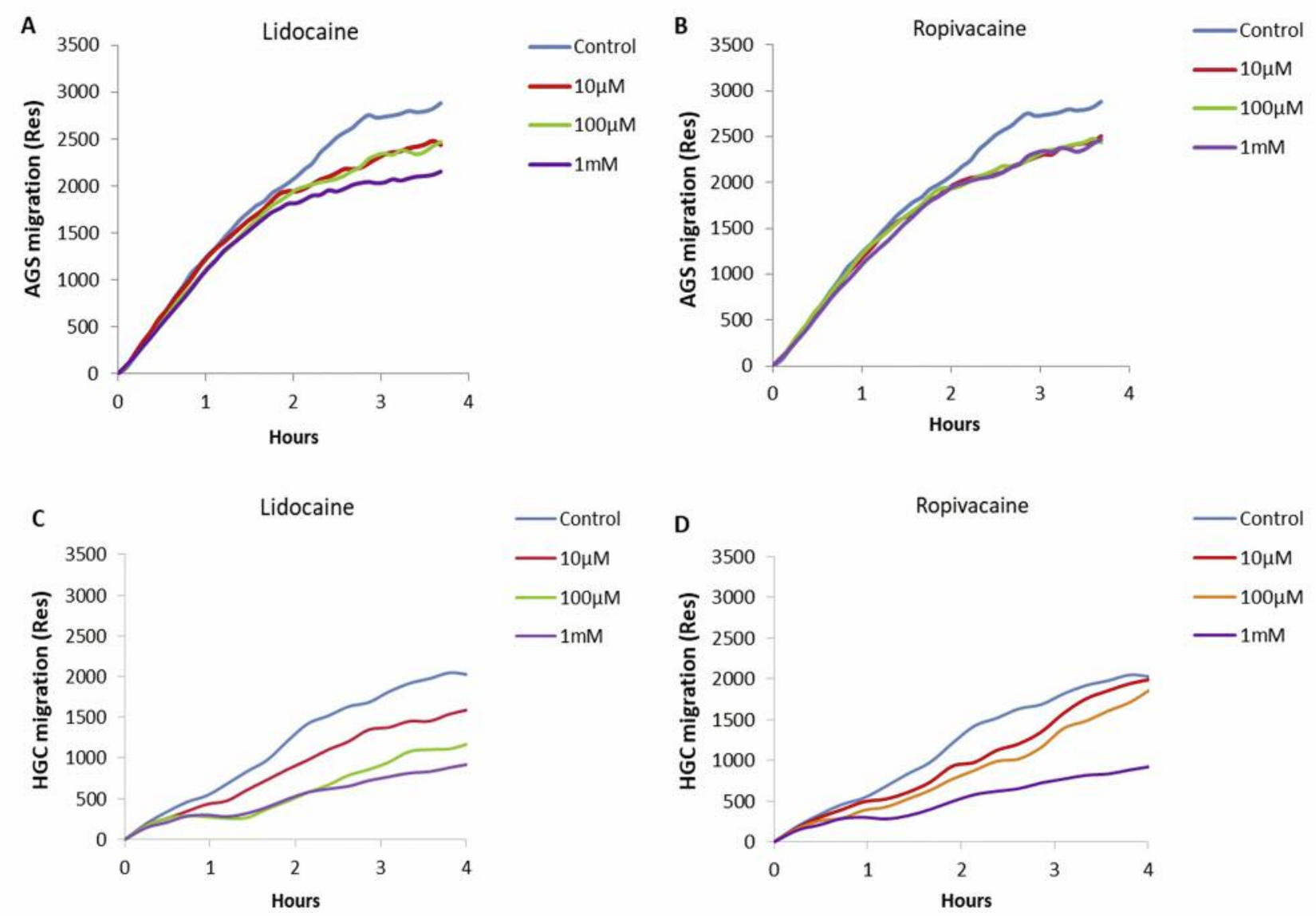

Figure 2. The effects of lidocaine and ropivacaine on migration, as shown by resistance (Res) using electric cell-substrate impedance sensing, of $A G S$ ( $A$ and $B$, respectively) and $H G C-27$ ( $C$ and $D$, respectively) cells. The data are means $\pm S D$.

can simultaneously inhibit the proliferation of gastric cancer and liver cancer, whether it has broad-spectrum antitumor effects still needs further study. It is supposed that by functional modifications or combination with other drugs, lidocaine might achieve greater anticancer effects. The combination of lidocaine with cisplatin has been proposed as a novel treatment option for hepatocellular carcinoma (19). In this study, we found that lidocaine significantly inhibited the proliferation of AGS and HGC-27 cells at an effective concentration of $10 \mu \mathrm{M}$ within $72 \mathrm{~h}$ with important clinical significance, whilst ropivacaine had an inhibitory effect on gastric cells at $1 \mathrm{mM}$, which is a much higher dose that can only be achieved by local infiltration clinically. This differs from the study of Lucchinetti et al. on mesenchymal stem cells (24), in which the effective concentration was found to be $100 \mu \mathrm{M}$. Our result indicates that lidocaine may be a better choice than ropivacaine in gastric cancer resection.

In addition, we investigated the effects of lidocaine and ropivacaine on cell migration. Cell migration is related to metastasis and recurrence of cancer. Lidocaine at low concentration exhibited a better effect on cell migration (as resistance by ECIS) on these two cell lines than ropivacaine, which indicated that lidocaine may be a good choice to improve prognosis.

We also explored the possible mechanism underlying these effects. Gastric carcinoma cell proliferation is significantly associated with the activation of the mitogenactivated protein kinase (MAPK) pathway (25). High epidermal growth factor receptor (EGFR) levels in gastric carcinoma are indicated as being associated with disease prognosis (26). EGFR acts as a cell surface receptor of extracellular ligands. Activation of EGFR initiates intracellular signals, including the central RAS/RAF/MAPK signalling pathway. ERK1/2 was found to be activated in gastric cancer as the final effectors of MAPK pathway (25). In this study, we demonstrated that on treatment with $1 \mathrm{mM}$ lidocaine or ropivacaine, the expression of $\mathrm{p}-\mathrm{ERK} 1 / 2$ in AGS and HGC-27 cells was significantly reduced compared with the control, suggesting that the antiproliferative effect of lidocaine and ropivacaine on AGS and HGC-27 cells is 




Figure 3. The effects of lidocaine and ropivacaine on the invasion of HGC cells (A) and AGS cells (B). The data are means $\pm S D$.

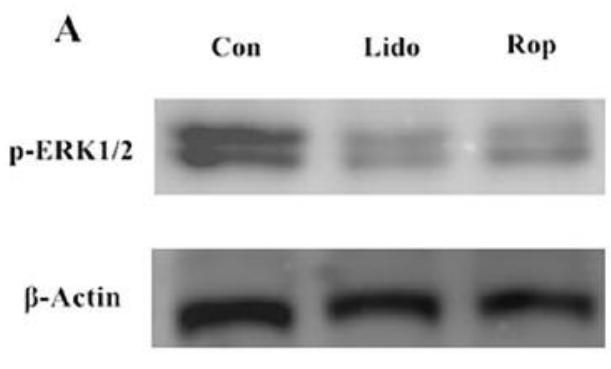

AGS

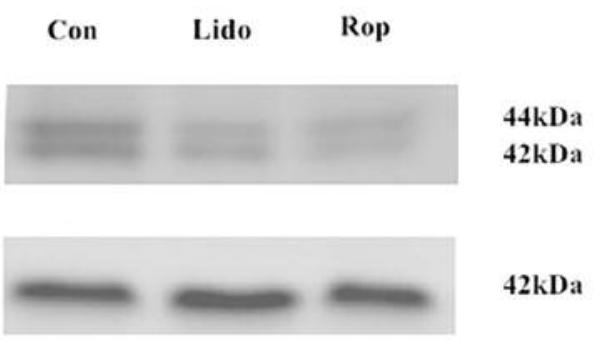

HGC

B

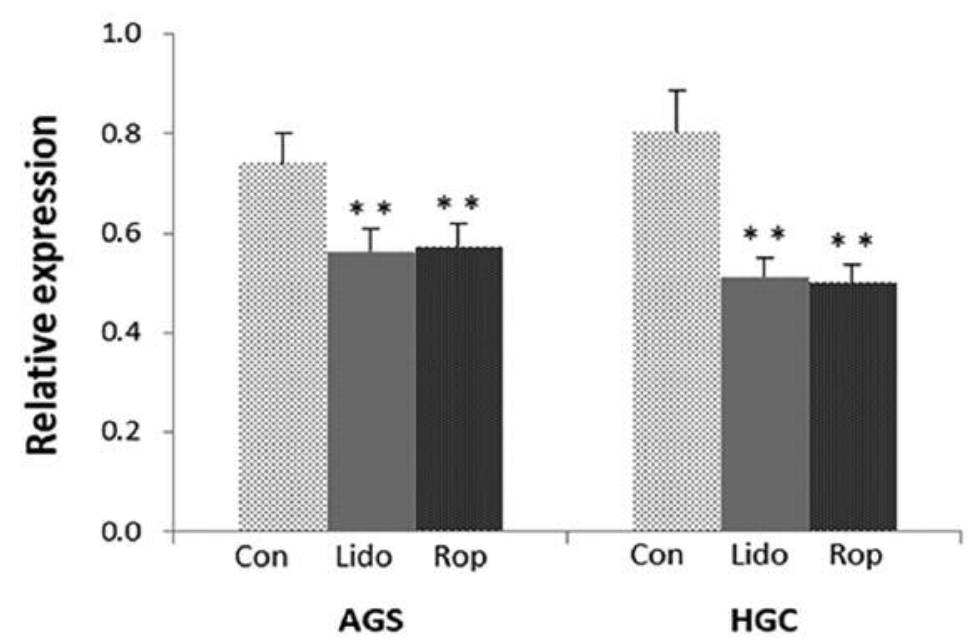

Figure 4. Western blots $(A)$ and quantitative analysis $(B)$ of phosphorylation of extracellular-regulated protein kinases (p-ERK1/2) in AGS and HGC-27 cells. **Significantly different at $p<0.01$ compared with control, after treatment with $1 \mathrm{mM}$ of lidocaine (Lido) and of ropivacaine (Rop) for $24 \mathrm{~h}$. The data are means \pm SD. 
associated with reduced activation of MAPK pathway by down-regulating ERK1/2 phosphorylation in vitro.

Compared to other studies, a lower concentration of lidocaine $(10 \mu \mathrm{M})$ had an antiproliferative effect on gastric cancer cells. Wang et al. discovered that lidocaine and ropivacaine significantly inhibited the migration and invasion of human non-small cell lung cancer cells (23). In addition, an in vivo mouse model showed that lidocaine inhibited distant lung metastasis of murine osteosarcoma cells (27). However, the concentrations they used were higher than 1 $\mathrm{mM}$. It was reported that lidocaine effectively inhibited the invasion of human cancer cells (HT1080, HOS, and RPMI$7951)$ at 5-20 mM, the concentration of which can only be achieved by infiltration anaesthesia in surgical operations (20). A previous study showed that lidocaine and ropivacaine had no effect on cell viability at concentrations up to $1 \mathrm{mM}$, whilst in this study, lidocaine and ropivacaine had antiproliferative effect on gastric cancer cells (10-1 mM), especially at $1 \mathrm{mM}$.

Piegeler et al. reported that lidocaine $(10 \mu \mathrm{M})$ and ropivacaine $(1 \mu \mathrm{M})$ completely blocked the tumor necrosis factor $\alpha$-induced increase in invasion of lung adenocarcinoma cells in vitro (28). We observed that both lidocaine and ropivacaine at $1 \mathrm{mM}$ and lower concentrations had no effect on the invasion of gastric cells. The results were similar for the adhesion and migration of gastric cancer cells with either lidocaine or ropivacaine at 10 or $100 \mu \mathrm{M}$. The inhibitory effects of LAs on the invasion and migration of cancer cells may be tissue-specific.

In conclusion, our study showed that both lidocaine and ropivacaine can significantly inhibit the proliferation of gastric cancer cells in vitro. The mechanism was by affecting the MAPK pathway via reduction of phosphorylation of EKR1/2. The results implied the additional benefit of the application of lidocaine and ropivacaine on patients with gastric cancer during the perioperative period, providing a reference for future study on gastric cancer surgery.

\section{Conflicts of Interest}

The Authors declare no conflicts of interest.

\section{Acknowledgements}

The Authors thank everyone who provided technical support in this study.

\section{References}

1 Fitzmaurice C, Dicker D, Pain A, Hamavid H, Moradi-Lakeh M, MacIntyre MF, Allen C, Hansen G, Woodbrook R, Wolfe C, Hamadeh RR, Moore A, Werdecker A, Gessner BD, Te Ao B, McMahon B, Karimkhani C, Yu C, Cooke GS, Schwebel DC, Carpenter DO, Pereira DM, Nash D, Kazi DS, De Leo D, Plass D,
Ukwaja KN, Thurston GD, Yun Jin K, Simard EP, Mills E, Park EK, Catala-Lopez F, deVeber G, Gotay C, Khan G, Hosgood HD, 3rd, Santos IS, Leasher JL, Singh J, Leigh J, Jonas JB, Sanabria J, Beardsley J, Jacobsen KH, Takahashi K, Franklin RC, Ronfani L, Montico M, Naldi L, Tonelli M, Geleijnse J, Petzold M, Shrime MG, Younis M, Yonemoto N, Breitborde N, Yip P, Pourmalek F, Lotufo PA, Esteghamati A, Hankey GJ, Ali R, Lunevicius R, Malekzadeh R, Dellavalle R, Weintraub R, Lucas R, Hay R, RojasRueda D, Westerman R, Sepanlou SG, Nolte S, Patten S, Weichenthal S, Abera SF, Fereshtehnejad SM, Shiue I, Driscoll T, Vasankari T, Alsharif U, Rahimi-Movaghar V, Vlassov VV, Marcenes WS, Mekonnen W, Melaku YA, Yano Y, Artaman A, Campos I, MacLachlan J, Mueller U, Kim D, Trillini M, Eshrati B, Williams HC, Shibuya K, Dandona R, Murthy K, Cowie B, Amare AT, Antonio CA, Castaneda-Orjuela C, van Gool CH, Violante F, Oh IH, Deribe K, Soreide K, Knibbs L, Kereselidze M, Green M, Cardenas R, Roy N, Tillmann T, Li Y, Krueger H, Monasta L, Dey S, Sheikhbahaei S, Hafezi-Nejad N, Kumar GA, Sreeramareddy CT, Dandona L, Wang H, Vollset SE, Mokdad A, Salomon JA, Lozano R, Vos T, Forouzanfar M, Lopez A, Murray C and Naghavi M: The global burden of cancer 2013. JAMA Oncol 1: 505-527, 2015.

2 Karimi P, Islami F, Anandasabapathy S, Freedman ND and Kamangar F: Gastric cancer: descriptive epidemiology, risk factors, screening and prevention. Cancer Epidemiol Biomarkers Prev 23: 700-713, 2014.

3 Tirino G, Pompella L, Petrillo A, Laterza MM, Pappalardo A, Caterino M, Orditura M, Ciardiello F, Galizia G and De Vita F: What's new in gastric cancer: The therapeutic implications of molecular classifications and future perspectives. Int J Mol Sci 19: 2659-2680, 2018.

4 Gockel I and Hoffmeister A: Endoscopic or surgical resection for gastro-esophageal cancer. Dtsch Arztebl Int 115: 513-519, 2018.

5 Slagter AE, Jansen EPM, van Laarhoven HWM, van Sandick JW, van Grieken NCT, Sikorska K, Cats A, Muller-Timmermans P, Hulshof M, Boot H, Los M, Beerepoot LV, Peters FPJ, Hospers GAP, van Etten B, Hartgrink $\mathrm{HH}$, van Berge Henegouwen MI, Nieuwenhuijzen GAP, van Hillegersberg R, van der Peet DL, Grabsch HI and Verheij M: CRITICS-II: a multicentre randomised phase II trial of neo-adjuvant chemotherapy followed by surgery versus neo-adjuvant chemotherapy and subsequent chemoradiotherapy followed by surgery versus neo-adjuvant chemoradiotherapy followed by surgery in resectable gastric cancer. BMC Cancer 18: 877, 2018.

6 Liao S, Zhou S and Wang C: GAPLINC is a predictor of poor prognosis and regulates cell migration and invasion in osteosarcoma. Biosci Rep 38: 1-8, 2018.

7 Li T, Huang H, Shi G, Zhao L, Li T, Zhang Z, Liu R, Hu Y, Liu $\mathrm{H}, \mathrm{Yu} \mathrm{J}$ and Li G: TGF-beta1-SOX9 axis-inducible COL10A1 promotes invasion and metastasis in gastric cancer via epithelial-to-mesenchymal transition. Cell Death Dis 9: 849-868, 2018.

8 Gao J, Wang H, Zang W, Li B, Rao G, Li L, Yu Y, Li Z, Dong B, Lu Z, Jiang Z and Shen L: Circulating tumor DNA functions as an alternative for tissue to overcome tumor heterogeneity in advanced gastric cancer. Cancer Sci 108: 1881-1887, 2017.

9 Youn GJ and Chung WC: Micrometastasis in Gastric Cancer. Korean J Gastroenterol 69: 270-277, 2017.

10 Nordgard O, Tjensvoll K, Gilje B and Soreide K: Circulating tumour cells and DNA as liquid biopsies in gastrointestinal cancer. Br J Surg 105: e110-e120, 2018. 
11 Kang HM, Kim GH, Jeon HK, Kim DH, Jeon TY, Park DY, Jeong H, Chun WJ, Kim MH, Park J, Lim M, Kim TH and Cho YK: Circulating tumor cells detected by lab-on-a-disc: Role in early diagnosis of gastric cancer. PloS one 12: e0180251, 2017.

12 Kamitani N, Watanabe A, Kirihataya Y and Ko S: Metachronous skeletal muscle metastasis without any other organ metastases after curative gastrectomy: a case report. Surg Case Rep 4: 98, 2018.

13 Yang Z, Zeng H, Xia R, Liu Q, Sun K, Zheng R, Zhang S, Xia C, Li H, Liu S, Zhang Z, Liu Y, Guo G, Song G, Zhu Y, Wu X, Song B, Liao X, Chen Y, Wei W, Zhuang G and Chen W: Annual cost of illness of stomach and esophageal cancer patients in urban and rural areas in China: A multi-center study. Chin J Cancer Res 30: 439-448, 2018.

14 Bajwa SJ, Anand S and Kaur G: Anesthesia and cancer recurrences: The current knowledge and evidence. J Cancer Res Ther 11: 528-534, 2015.

15 Wang HW, Wang LY, Jiang L, Tian SM, Zhong TD and Fang XM: Amide-linked local anesthetics induce apoptosis in human non-small cell lung cancer. J Thorac Dis 8: 2748-2757, 2016.

16 Jurj A, Tomuleasa C, Tat TT, Berindan-Neagoe I, Vesa SV and Ionescu DC: Antiproliferative and apoptotic effects of lidocaine on human hepatocarcinoma cells. A preliminary study. J Gastrointestin Liver Dis 26: 45-50, 2017.

17 Lirk P, Berger R, Hollmann MW and Fiegl H: Lidocaine timeand dose-dependently demethylates deoxyribonucleic acid in breast cancer cell lines in vitro. Br J Anaesth 109: 200-207, 2012.

18 Chang YC, Hsu YC, Liu CL, Huang SY, Hu MC and Cheng SP: Local anesthetics induce apoptosis in human thyroid cancer cells through the mitogen-activated protein kinase pathway. PloS one 9: e89563, 2014.

19 Xing W, Chen DT, Pan JH, Chen YH, Yan Y, Li Q, Xue RF, Yuan YF and Zeng WA: Lidocaine induces apoptosis and suppresses tumor growth in human hepatocellular carcinoma cells in vitro and in a xenograft model in vivo. Anesthesiology 126: 868-881, 2017.

20 Bundscherer A, Malsy M, Gebhardt K, Metterlein T, Plank C, Wiese $\mathrm{CH}$, Gruber M and Graf BM: Effects of ropivacaine, bupivacaine and sufentanil in colon and pancreatic cancer cells in vitro. Pharmacological research 95-96: 126-131, 2015.
21 Byrne K, Levins KJ and Buggy DJ: Can anesthetic-analgesic technique during primary cancer surgery affect recurrence or metastasis? Can J Anaesth 63: 184-192, 2016.

22 Xuan W, Hankin J, Zhao H, Yao S and Ma D: The potential benefits of the use of regional anesthesia in cancer patients. Int J Cancer 137: 2774-2784, 2015.

23 Vaghari BA, Ahmed OI and Wu CL: Regional anesthesiaanalgesia: Relationship to cancer recurrence and infection. Anesthesiol Clin 32: 841-851, 2014.

24 Lucchinetti E, Awad AE, Rahman M, Feng J, Lou PH, Zhang L, Ionescu L, Lemieux $\mathrm{H}$, Thebaud $\mathrm{B}$ and Zaugg $\mathrm{M}$ : Antiproliferative effects of local anesthetics on mesenchymal stem cells: potential implications for tumor spreading and wound healing. Anesthesiology 116: 841-856, 2012.

25 Liang B, Wang S, Zhu XG, Yu YX, Cui ZR and Yu YZ: Increased expression of mitogen-activated protein kinase and its upstream regulating signal in human gastric cancer. World $\mathbf{J}$ Gastroenterol 11: 623-628, 2005.

26 Kim MA, Lee HS, Lee HE, Jeon YK, Yang HK and Kim WH: EGFR in gastric carcinomas: Prognostic significance of protein overexpression and high gene copy number. Histopathology 52 : 738-746, 2008

27 Piegeler T, Vottavelis EG, Liu G, Place AT, Schwartz DE, Beckschimmer B, Minshall RD and Borgeat A: Antimetastatic potential of amide-linked local anesthetics: inhibition of lung adenocarcinoma cell migration and inflammatory Src signaling independent of sodium channel blockade. Anesthesiology 117: 548-559, 2012.

28 Piegeler T, Schlapfer M, Dull RO, Schwartz DE, Borgeat A, Minshall RD and Beck-Schimmer B: Clinically relevant concentrations of lidocaine and ropivacaine inhibit TNFalphainduced invasion of lung adenocarcinoma cells in vitro by blocking the activation of AKT and focal adhesion kinase. Br J Anaesth 115: 784-791, 2015.

Received October 11, 2018

Revised October 24, 2018

Accepted October 26, 2018 